Paweł Drobny

Cracow University of Economics

Faculty of Economics and International Relations

Department of Microeconomics

e-mail: drobnyp@uek.krakow.pl

\title{
Zakaz handlu w niedziele jako przejaw pozytywnej interwencji państwa w rynek. Ujęcie personalistyczne
}

\section{The prohibition of trade on sunday as a manifestation of positive state intervention in the market. A personalistic approach}

The article is an attempt to look at the relationship between the state and the market on the example of the prohibition of trade on Sunday through the prism of the personalistic economy. The article has a metaeconomic character. Its aim is to show that state intervention in the market mechanism in the form of the prohibition of trade on Sunday is not aimed at trade as an economic activity, but is a natural consequence of the community-forming function of the state. In the first part, the author presents a personalistic approach to the state and the market as well as relations between them. In turn, in the second part, he describes the essence of the Sunday dispute in the context of a personalistic approach to the market and shows that state intervention, consisting in protecting Sunday from being limited to the seventh working day, protects it against rationalization and marketization, i.e. its derealization.

Keywords: state interventionism, personalist economics, person, market, state

JEL Classification: A11, A13, B59, D4, D6 


\section{Wprowadzenie}

Zakaz handlu w niedziele jest przejawem interwencji państwa w mechanizm rynkowy ${ }^{1}$. Takie działanie państwa stanowi ważny problem dla ekonomii, ponieważ w istocie dotyka człowieka w ogóle, a nie tylko tego wymiaru jego bytowania, który jest przedmiotem jej zainteresowania. Refleksja nad nim rodzi wątpliwość, czy współczesna ekonomia dysponuje właściwym dla sprawy sposobem ujęcia rzeczywistości. Wątpliwość ta jest uzasadniona, ponieważ w polskiej debacie publicznej i parlamentarnej, która toczy się nad wprowadzonymi przez rząd zmianami w zakresie handlu w niedziele (Ustawa z dnia 10 stycznia 2018 r. o ograniczeniu handlu $w$ niedziele i święta oraz $w$ niektóre inne dni), wszystkie strony sporu odwołują się przede wszystkim (jeśli nie tylko) do argumentów o charakterze ekonomicznym. Podczas wsłuchiwania się w tę debatę pojawiają się pytania, które wydają się pomijane przez środowisko ekonomistów, jakby wyczerpujące odpowiedzi na nie już padły. Oto one:

(1) Jaka jest relacja między państwem a rynkiem?

(2) Jakie stanowisko powinien zająć ekonomista w sporze między państwem a rynkiem?

(3) Czy spór ten nie obnaża prawdy o ekonomii, że opiera się ona na bardzo ograniczonych wizjach człowieka, a tym samym nie przyczynia się do rozwiązania problemów międzyludzkich, a wręcz je pogłębia?

W przypadku pytania pierwszego w ekonomii panuje stan zawieszenia. Wieloletni spór: ile państwa, a ile rynku, wydaje się nierozstrzygalny. Pomysły na rozwiązanie tego problemu opierają się tylko na przesunięciu akcentu w jedną bądź drugą stronę na linii sporu, a jego uczestnicy trwają raczej przy raz przyjętych stanowiskach. Także w kontekście prezentowanego problemu argumenty w debacie wynikają z pozycji, na jakich „okopali się” adwersarze: ile państwa, a ile rynku. $Z$ tej perspektywy poruszony w artykule problem nie może być rozwiązany z tych samych przyczyn, co problem ogólniejszy.

$\mathrm{Na}$ drugie pytanie również nie ma jednoznacznej odpowiedzi. Wydaje się, że dominuje ciche założenie, które można wyrazić słowami A. Jakimowicza (2012, s. 472): „Celem ekonomii jako nauki jest wyjaśnianie, przewidywanie oraz kształtowanie rzeczywistości”. Skoro więc ekonomista czuje się kreatorem rzeczywistości, to z założenia jego badania ukierunkowane są na preferowany przez niego model rzeczywistości. Zaangażowanie w kreowanie rzeczywistości przejawia się

\footnotetext{
${ }^{1}$ Poruszony w artykule problem nawiązuje do wcześniejszej pracy pt. „Wypieranie norm kulturowych przez normy rynkowe jako przejaw zawodności rynku" (Drobny, 2018, s. 199-222) i stanowi kontynuację myśli poświęconej relacji między rynkiem a kulturą. Wiąże się on także z prowadzoną aktualnie w Polsce dyskusją nad wprowadzonymi przez rząd zmianami w zakresie handlu w niedziele. Temat badawczy, w ramach którego powstał niniejszy tekst, dotyczy problemu interwencjonizmu państwowego jako reakcji na zawodność rynku. Chcemy więc w tym kontekście spojrzeć na relacje między państwem a rynkiem w zakresie ich działań na polu kultury. Będzie to spojrzenie, którego dokonamy przez pryzmat osoby i jej rozwoju. Spojrzenie to w innym miejscu zostało nazwane ekonomią personalistyczną (Drobny, 2016). Jednocześnie spojrzenie to będzie stanowiło podstawę do refleksji nad kondycją współczesnej myśli ekonomicznej.
} 
najczęściej, w kontekście omawianego problemu relacji między państwem a rynkiem, w tym, że jest on albo rzecznikiem grupy podmiotów działających na konkretnym rynku, albo rzecznikiem aparatu władzy. Konsekwencją tego jest zatarcie granic między nauką a polityką oraz wykorzystanie nauki do uzasadnienia lub zanegowania bieżących działań politycznych.

$\mathrm{Na}$ trzecie pytanie także nie ma jednoznacznej odpowiedzi. Wydaje się, że model homo oeconomicus, używany w ramach ekonomii neoklasycznej, nie odgrywa już znaczącej roli, a nawet przeczy ustaleniom innych dziedzin nauki. Inne modele człowieka, które leżą u podstaw ekonomii behawioralnej, ekonomii instytucjonalnej, ekonomii feministycznej etc., redukują ten obraz do wybranych aspektów i nie wychodzą od człowieka jako pewnej całości, tworząc, zdaniem niektórych, wzajemnie uzupełniające się jego ujęcia (Horodecka, 2018, s. 356). W używanych przez ekonomistów matematycznych modelach rynku i gospodarki człowiek rozmywa się w agregatach, które nie tyle wskazują na niego samego, co raczej na jego nastawienie (relację) do rzeczy, ale nie w ujęciu indywidualnym, tylko masowym. Jego różnorodność fizyczna i duchowa zdają się nie mieć znaczenia. Masowe podejście do człowieka jest bardzo praktyczne, zważywszy na chęć kreowania rzeczywistości, ale nieużyteczne na płaszczyźnie poszukiwania prawdy, a nawet krzywdzące z perspektywy poszczególnych ludzi lub ich grup, jeżeli jest ono uzasadnieniem dla konkretnych praktyk i polityk. Wydaje się, że ekonomii potrzebne jest takie spojrzenie na człowieka, które uwzględni jego różnorodność doświadczania świata i pozwoli na to, aby ekonomiczne analizy dotyczyły każdego człowieka i wszystkich przejawów jego egzystencji.

Niniejszy artykuł stanowi próbę spojrzenia na problem relacji między państwem i rynkiem na przykładzie zakazu handlu w niedziele przez pryzmat ekonomii personalistycznej. Ma on charakter metaekonomiczny. Jego celem jest wykazanie, że interwencja państwa w mechanizm rynkowy w postaci zakazu handlu w niedziele nie jest wymierzona w handel jako działalność gospodarczą, ale jest naturalną konsekwencją wspólnototwórczej funkcji państwa.

\section{Państwo a rynek - ujęcie personalistyczne}

Ustalenie relacji między państwem a rynkiem jest fundamentalnym zadaniem dla omawianej sprawy, ponieważ będzie stanowiło podstawę do określenia, czym jest interwencja państwa w rynek i jakie jest jej znaczenie.

$\mathrm{Na}$ gruncie ekonomii głównego nurtu panuje dowolność przejawiająca się w zamiennym stosowaniu takich pojęć, jak interwencjonizm państwowy, ingerencja państwa w gospodarkę itp. Wynika to, jak zauważył A. Wojtyna (1990, s. 16), „Z niejasności, czym w ogóle jest państwo”. Naszym zdaniem jest to raczej skutek bardzo hermetycznego i egocentrycznego podejścia ekonomii do badanych zjawisk społecznych. Ich ludzki wymiar wymaga podejścia kompleksowego, a nie ograniczonego wyłącznie do jakiegoś dalekiego od rzeczywistości modelu człowieka i jego zachowań. Problem państwa jest i był szeroko omawiany na gruncie 
innych dyscyplin nauki. Ekonomiści wydają się jednak zamknięci na wyniki badań w takich dziedzinach, jak filozofia, socjologia, politologia, antropologia czy prawo. W modelach ekonomicznych, na skutek przyjętych założeń, trudno odnaleźć społeczny wymiar życia ludzkiego. Z kolei jego wymiar gospodarczy jawi się w nich jako autonomiczny. Takie podejście nazwane zostało imperializmem ekonomicznym. Opiera się ono na przekonaniu, które dobrze wyraził G. S. Becker (1990, s. 26-27), pisząc:

\begin{abstract}
Podejście ekonomiczne jest podejściem najszerszym, dającym się zastosować do wszelkich zachowań ludzkich niezależnie od tego, czy chodzi o reakcje na ceny pieniężne czy na kalkulacyjne „ceny-cienie”, o decyzje powtarzające się czy podejmowane bardzo rzadko, o decyzje ważne czy mniej ważne, o cele o charakterze emocjonalnym czy mechanicznym, o osoby bogate czy ubogie, o mężczyzn czy o kobiety, o dorosłych czy o dzieci, o ludzi błyszczących inteligencją czy tępych, o pacjentów czy o lekarzy, o ludzi interesu czy o polityków, o nauczycieli czy o uczniów. Możliwości zastosowania podejścia ekonomicznego są równie szerokie, jak szeroki jest zakres ekonomii.
\end{abstract}

W podejściu tym dąży się do wzrostu wyjaśniającej unifikacji (Mäki, 2013). Próbuje się bowiem pojęciami z zakresu ekonomii objąć jak najszerszy obszar zjawisk społecznych, w tym kulturowych. Oznacza to zapoznanie pierwotnego znaczenia zjawisk i zredukowanie ich do znaczenia ekonomicznego. Dotyczy to także państwa. Ekonomiści wydają się widzieć w nim przede wszystkim funkcje ekonomiczne, a jego pozostałe role są o tyle istotne, o ile mają znaczenie dla realizacji funkcji ekonomicznych właśnie. Skoncentrowanie wyłącznie na funkcjach ekonomicznych państwa stanowi fundament w sporze o to, ile państwa, a ile rynku powinno być w gospodarce (Szarzec, 2013). Nawet jeżeli pojawiają się inne głosy w dyskusji, wskazujące na nieadekwatność tego sporu do rzeczywistości (Thaler \& Sunstein, 2012; Mazzucato, 2016; Chang, 2013), to nie są one na tyle silne, aby zmieniły myślenie ekonomistów; co więcej, nie pokazują alternatywy dla tego sporu, a jedynie przesuwają $\mathrm{w}$ nim akcenty lub role. Na przykład ekonomiści behawioralni wskazują na to, że rynek nie może istnieć bez państwa. Państwo natomiast powinno „rękami” swoich urzędników generować impulsy, które będą naprowadzać jednostki na racjonalne i korzystne dla nich decyzje w różnych dziedzinach życia (Thaler \& Sunstein, 2012, s. 286-287). Nie wskazują oni jednak, jakimi kryteriami powinni się kierować urzędnicy, generując owe impulsy, ani też nie wchodzą $w$ głębszą charakterystykę relacji między państwem a rynkami i gospodarką, nie próbują nawet opisać natury rynku i państwa. Z kolei M. Mazzucato (2016, s. 15-16) pokazuje państwo jako przedsiębiorcę, jako podmiot podejmujący ryzyko i jako twórcę rynków. Trudno tu jednak doszukać się szerszej wizji państwa i rynku. Na tym tle interesujące stanowisko zajmuje antropolog D. Graeber, który, podając w wątpliwość mit o fundamentalnej dla ekonomii roli pieniądza i przypisując tę rolę długowi, stwierdził: 
Mimo wciąż utrzymującej się liberalnej sugestii - wywodzącej się, jak poprzednio, od Smitha - że państwa i rynki są w jakiś sposób ze sobą sprzeczne, świadectwa historyczne pokazują, że prawda jest dokładnie odwrotna. W społeczeństwach, w których nie ma państwa, zwykle nie ma również rynków. (Graeber, 2017, s. 71)

Ponieważ artykuł nie ma charakteru monografii poświęconej ani samemu państwu, ani relacjom między państwem a gospodarką, ograniczymy się do zaprezentowania personalistycznego ujęcia relacji między państwem a rynkiem, a także próby zdefiniowania, czym $\mathrm{w}$ takim ujęciu jest interwencja państwa $\mathrm{w}$ mechanizm rynkowy.

Dlaczego ujęcie personalistyczne? Ponieważ personalizm jest realistyczno-egzystencjalnym ujęciem człowieka we wszystkich jego wymiarach. Uznaje on jedność ontyczną osoby, tzn. wszystkie wymiary jej bytu cielesno-duchowo-psychicznego. Personalistyczna wizja człowieka zapewnia więc integralne jego rozumienie: jego natury, właściwości, potrzeb, powołania (Kowalczyk, 1992, s. 44). Powstały na tym gruncie humanizm, który J. Maritain nazwał humanizmem integralnym, „dąży z istoty swej do uczynienia człowieka bardziej ludzkim i do okazania jego pierwotnej wielkości przez wprowadzenie go w uczestnictwo w tym wszystkim, co może go ubogacić w naturze i w historii („koncentrując świat w człowieku” według słów Schelera i „rozszerzając człowieka na świat”). Żąda on jednocześnie, by człowiek rozwinął możliwości w nim zawarte, siły twórcze i życie rozumu i by dążył do uczynienia sił świata fizycznego narzędziami swojej wolności” (Maritain, 1960, s. 10). Takie ujęcie pozwala wyrwać się z uścisku dwóch wielkich ruchów, które są sobie przeciwstawne, ale tak samo obojętne w odniesieniu do osoby, tj. liberalnego indywidualizmu oraz socjalizmu.

Charakterystyka personalistycznego ujęcia państwa wymaga porządku. Po pierwsze, jej punktem wyjścia powinna być prezentacja stanowiska, które jest fundamentalne dla tego ujęcia, tj. prezentacja rozumienia człowieka jako osoby. Po drugie, konieczne jest ukazanie uczestnictwa jako sposobu (współ)bycia i (współ)działania osób z sobą, które urzeczywistnia wartość, jaką jest dobro wspólne. Po trzecie, należy ukazać państwo za rodzaj porządku, który służy urzeczywistnieniu dobra wspólnego.

Wszelkie doświadczenie człowieka zakorzenione jest w jego wewnętrznym ,ja", które jest jego bytowym centrum i sprawcą. Podstawowym doświadczeniem człowieka jest doświadczenie „bycia człowiekiem”. W świadomych przeżyciach człowiek rejestruje własną podmiotowość, która wyraża się jako ,ja” działające i odbierające oddziaływania „z zewnątrz”. Rejestruje siebie jako ,ja” istniejące samo w sobie, jako podmiot, z którego wychodzą różne „moje” czynności. Doświadczenie ,ja” i „moje” stanowi doświadczenie „,bycia człowiekiem”, „,bycia osobą”.

$\mathrm{Z}$ punktu widzenia omawianego tematu istotne jest uchwycenie w doświadczeniu wewnętrznym człowieka relacji między ,ja” a „moje”. Z jednej strony ,ja” uobecnia się w „moje” (immanencja), a z drugiej ,ja” przekracza „moje” (transcendencja). Doświadczenie immanencji ,ja” w „moje” stanowi podstawę: własno- 
ści, odpowiedzialności, porządku społecznego. Z kolei transcendencja ,ja” wobec „moje” pokazuje, że człowiek jest ponad tym, co działa, i ponad tym, co jest treścią jego działania (Krąpiec, 2005, s. 8-14).

Równolegle do doświadczenia wewnętrznego człowiekowi dane jest, przez jego cielesność, doświadczenie zewnętrzne. W doświadczeniu tym człowiek widzi siebie jako tego, który nie podlega całkowicie prawom natury. Posiada on bowiem umiejętność jej przekształcania, uzupełniania i doskonalenia. Odkrywa tym samym siebie jako twórcę kultury i cywilizacji.

Doświadczenie „bycia osobą” ma zatem jednocześnie wymiar materialny i duchowy. Tym, co je łączy w człowieku, co stanowi owo „centrum”, jest dusza. Jest ona źródłem tożsamości bytu i jego niepodzielności. Z personalistycznej perspektywy człowiek jest więc jednością duszy i ciała, które tworzą substancję ludzką jako monolit. Nie jest on ani samą duszą, ani samym ciałem. Bycie osobą jest wynikiem czynnika duchowego. Dusza w człowieku nie jest osobą, ale jest zasadą osobowości. Osobą jest dopiero pełny człowiek.

Momentem, w którym człowiek jawi się jako osoba, jest jego czyn. Fenomenologiczna analiza czynu pokazuje, że tylko w nim człowiek stwierdza bezpośrednio, iż jest on jego sprawcą, to znaczy, że jest on jego własnością i czuje się za niego odpowiedzialny. Dzięki analizie przeżycia ,ja działam” można więc zauważyć, że z jednej strony człowiek jest immanentny wobec swojego czynu, to znaczy pozostaje wewnątrz tego czynu, a z drugiej strony jest wobec niego transcendentny, to znaczy nie jest jego częścią, ale panuje nad nim. Czyn jest więc wyrazem stanowienia człowieka o sobie. Samostanowienie ukazuje zaś właściwą mu strukturę samoposiadania i samopanowania. Aby człowiek mógł za pomocą woli stanowić o sobie, musi siebie samego posiadać i nad sobą panować. Jedno i drugie warunkuje samostanowienie i jednocześnie urzeczywistnia się w samostanowieniu (Wojtyła, 2000, s. 152).

Analiza osobowej struktury samostanowienia pokazuje, że człowiek przez swoje działanie określa i kształtuje samego siebie, a także urzeczywistnia swoją wartość. Jest więc nie tylko sprawcą, ale też twórcą swojego działania. Poprzez czyny spełnia się, to znaczy działając, rozwija się albo też niszczy się.

Jako byt spotencjalizowany człowiek jest wezwany do dążenia do pełni. Pozytywną odpowiedzią na to wezwanie jest jego integralny rozwój, który należy rozumieć jako aktualizację potencjalności ludzkich, takich jak zdolność poznania, miłości i twórczości (Krąpiec, 2009, s. 169). Dzięki swej rozumności i wolnej woli człowiek poznaje, akceptuje i wybiera środki, dzięki którym jeszcze pełniej staje się człowiekiem w dziedzinie poznania, postępowania i twórczości. Dzięki aktom autodeterminacji aktualizuje on swoje życie osobowe. Spełnianie czynu przez osobę urzeczywistnia tzw. wartość personalistyczną (Wojtyła, 2000, s. 304).

Człowiek nie jest bytem autarkicznym, mimo że jest bytem autonomicznym. Jego natura wymaga życia społecznego. Dlatego jego czyny spełniane są w różnych relacjach międzyludzkich (ja-ty) oraz relacjach społecznych (my), czyli „wspólnie z innymi” ludźmi. Jeżeli człowiek działa „wspólnie z innymi” i jednocześnie urzeczywistnia wspomnianą wartość personalistyczną, wówczas można mówić o tzw. uczestnictwie. Poprzez uczestnictwo osoba realizuje to, co wynika 
ze wspólnoty działania, a jednocześnie przez to, co realizuje, „tworzy się” i rozwija (Wojtyła, 2000, s. 308-309). Działanie „wspólnie z innymi” ma charakter współdziałania wtedy, gdy wyzwala moment uczestnictwa. W tym też tkwi różnica między społeczeństwem a wspólnotą. Wspólnota opiera się na uczestnictwie, dlatego też jest ona czymś bardziej właściwym dla osobowej podmiotowości członków danego społeczeństwa. Gdy zanika wspólnota, gdy zanika uświadomiona i przeżywana przez osoby więź, dochodzi do „rozluźnienia” relacji, a w konsekwencji do alienacji osób.

Oprócz uczestnictwa wspólnotę od społeczeństwa odróżnia także stosunek jej członków do dobra wspólnego. Uwzględniając zarówno wymiar przedmiotowy, jak i podmiotowy, można powiedzieć, że dobrem wspólnym jest „nie tylko cel działania wypełnianego w jakieś wspólnocie [...] ale jest nim zarazem i nawet przede wszystkim to, co warunkuje i niejako wyzwala uczestnictwo w osobach działających wspólnie i przez to kształtuje w nich podmiotową wspólnotę działania" (Wojtyła, 2000, s. 321). Dobro wspólne jest więc zasadą prawidłowego uczestnictwa. Trzeba jednak pamiętać, że uczestnictwo inaczej przejawia się i urzeczywistnia w doraźnych wspólnotach, na przykład w przedsiębiorstwie, a inaczej we wspólnotach stałych, jak chociażby rodzina czy naród. W tych ostatnich potrzeba uczestnictwa jest większa, a ono samo głębsze.

Życie społeczne wyrasta z natury człowieka i jest konsekwencją potencjalności i przygodności jego bytu (Kowalczyk, 2005, s. 118-119). Dopełnia ono osobę i przyczynia się do jej rozwoju. Istnienie wolnych i rozumnych osób jest więc warunkiem powstania społeczności, a nie na odwrót (Krąpiec, 1982, s. 38). Relacje, które tworzą społeczność, służą więc aktualizowaniu osobowych potencjalności poprzez urzeczywistnianie dobra wspólnego. Osoba w takim ujęciu nie jest ani egzemplarzem większej całości, ani doskonałą monadą niewiążącą się z innymi i budującą społeczeństwo tylko w oparciu o umowę.

W ujęciu personalistycznym przyjmuje się, że życie społeczne osób opiera się nie tylko na podstawach biologicznych, ale także na podstawach psychiczno-duchowych. Ludzie uczestniczą w społeczności nie tylko po to, aby zachować życie biologiczne, ale także po to, aby rozwinąc życie osobowe (duchowe) poprzez rozwój intelektualny, moralny i twórczy. Czynią to poprzez wspólne urzeczywistnianie wartości w różnych typach życia społecznego, takich jak na przykład: rodzina, gmina, naród, państwo, społeczność międzynarodowa. Wyrazem tych wspólnych czynów są postawy, instytucje, rzeczy, które składają się na kulturę i cywilizację. Cywilizacja to „wszystko, co ludzkość stworzyła, dodała do natury dla ułatwienia i ulepszenia życia i co wielu ludziom jest wspólne”. Składają się na nią rzeczy, które zostały wytworzone przez ludzi, ponieważ były im potrzebne, czynności, dla których te rzeczy zostały wytworzone, ustrój, moralność, religia, wiedza, smak artystyczny oraz ideologia (Tatarkiewicz, 1978, s. 80-81). Z kolei kultura to „przeżycia i czynności poszczególnych ludzi, którzy wydali cywilizację i z cywilizacji korzystają” (s. 76). Kultura stanowi więc bogactwo duchowe człowieka.

Aby życie społeczne mogło się toczyć względnie bez przeszkód, konieczne jest istnienie władzy, która gwarantując pokój społeczny, zapewnia społeczny porządek. Potrzebne jest zatem państwo. W ujęciu personalistycznym państwo jest naczelną 
społecznością ludzką, którą tworzą takie czynniki, jak: system prawa i władzy, terytorium oraz naród (lud, poddani). Jest ono naturalnym tworem ludzkim, który powstał dla realizacji dobra wspólnego. Może ono bowiem tak zorganizować środki służące dobru poszczególnych osób, że każdy, stosownie do swych przymiotów wrodzonych i nabytych, zgodnie z zainteresowaniami, poprzez pracę może się rozwijać.

Pierwszym czynnikiem strukturalizującym państwo jest system prawny, który jest wyrazem organizacji państwowej. Dzięki niemu ustalone zostają zasady działania takich instytucji, jak: urzędy, szkoły, szpitale, przedsiębiorstwa, teatry, kina itp., będących wyrazem ludzkich oczekiwań w zakresie nauki, techniki, kultury i gospodarki. Prawo racjonalnie porządkuje ludzkie czynności dla dobra wspólnego. Umocnieniem systemu prawnego jest system władzy. Państwo jest więc także organizacją naturalnego przymusu. Przymus ten jest racjonalny, jeśli służy realizacji dobra wspólnego, a nie wyłącznie dobra poszczególnych grup społecznych. Równie istotnymi czynnikami konstytuującymi państwo są terytorium i naród, a także zadania, jakie wobec narodu posiada państwo (Krąpiec, 2007, s. 78-95). Charakterystyka tych czynników nie będzie jednak przedmiotem tego opracowania.

W personalistycznej koncepcji państwa istotnym elementem jest podkreślenie jego celu, czyli dobra wspólnego. Wyraża się ono w urzeczywistnianiu wartości zarówno wyższych, jak i niższych, które są niezbędne do wszechstronnego rozwoju osób. Dbanie o pokój wewnętrzny i zewnętrzny, integracja społeczna i kulturalna, bezpieczeństwo socjalne, sprawiedliwość, wartości etyczne i religijne to tylko niektóre z nich (Kowalczyk, 2005, s. 245). Dobro wspólne ma wymiar zarówno podmiotowy, jak i przedmiotowy, dlatego aktualizacja dobra wspólnego wymaga środków materialnych. Te zaś powinny być tak wytwarzane i rozdzielane, aby każdemu dać szansę realizowania dobra osobistego według jego możliwości.

Mechanizmem, który służy podziałowi dóbr, jest rynek. Jest to narzędzie utrzymywania porządku przez organ władzy, jakim jest na przykład państwo. Jego funkcją jest taka organizacja wymiany, która służy dobru wspólnemu. Organizacja ta polega na tworzeniu warunków do swobodnej, ale i bezpiecznej, bo odpowiedzialnej, wymiany dóbr i usług. Rodzi się pytanie, o jaki nieporządek może tu chodzić i kto lub co go wywołuje. Odpowiadając na nie, możemy posłużyć się pojęciem „entropii” zapożyczonym z fizyki. Pojawia się ono w kontekście pierwszej i drugiej zasady termodynamiki. Oba te prawa można ująć w jednym zdaniu: „ilość całkowitej energii we wszechświecie jest stała, a całkowita entropia bezustannie rośnie" (Asimov, 1970, s. 9). Oznacza to, że ilości energii nie można zmienić. Jednakże za każdym razem, kiedy energia jest przetwarzana $z$ jednego stanu w drugi, utracona zostaje pewna jej część, która mogłaby zostać wykorzystana w przyszłości. To zjawisko nazywa się entropią (Rifkin \& Howard, 2008, s. 49). To, co możemy więc zaobserwować w naturze, to przechodzenie od stanu porządku do nieporządku. Ponieważ ludzie są częścią natury, także w ich relacjach zaobserwować można zjawisko entropii (nieporządku) (Pinker, 2018, s. 33-47). Jak zauważył R. Spaemann, druga zasada termodynamiki wyraża „uniwersalny bieg rzeczy”. W związku z tym ,,automatyzm wszelkiego niekontrolowanego rozwoju zmierza do rozbicia struktur, do nieporządku, do niwelacji i ostatecznie do śmierci” (Spaemann, 2006, s. 469). 
Źródłem nieporządku w relacjach międzyludzkich jest niczym nieograniczona ludzka rywalizacja, oparta na zasadach „wszystko wolno” oraz „cel uświęca środki”. Nie mówimy tu jednak o czystej rywalizacji, jaką opisują neoklasyczne modele, opartej wyłącznie na racjonalnych, zoptymalizowanych decyzjach ukierunkowanych na wybrane, wymierne cele, pozbawionej emocji, a także błędów wynikających z braku wiedzy, umiejętności i informacji, w której używa się jako narzędzia kalkulacji idealnego środka pomiaru wartości i wymiany dóbr. Relacje, które w ramach rywalizacji powstają między ludźmi, są głęboko osadzone w biologii ich ciał, w ich codziennych praktykach służących życiu, w ich problemach i stanowią one część przeżywanego przez tych ludzi świata.

Przeciwstawiając się postępującej entropii, ludzie rzadko robią to samotnie. Organizują się w społeczności, nadają im sens i konstruują zasady i normy postępowania, które mają służyć tej społeczności. Jak zauważył R. Spaemann (2006, s. 469):

państwo prawa jest wielkim przedsięwzięciem skierowanym przeciwko trendowi, przeciwko temu, co by się stało, gdybyśmy się mu nie przeciwstawili. Tym, co przebija się samo z siebie, jest co najwyżej prawo silniejszego [...] właśnie tej tendencji do samozniszczenia przeciwstawia się nasze prawo.

Ta powszechna organizacja ma zatem chronić społeczność przed marnowaniem energii. Jednym z przejawów tej organizacji jest właśnie rynek.

Myślenie o rynku jako o doskonałym mechanizmie alokacji dóbr, na który człowiek nie ma żadnego wpływu i któremu musi się podporządkować, jest konsekwencją budowania takiej narracji w postaci różnych teorii, najczęściej neoklasycznej teorii równowagi rynkowej; teorie te, jak słusznie zostało zauważone, stanowią współczesną formę mitów tłumaczących ludziom świat ${ }^{2}$. Tymczasem w naturę mechanizmu rynkowego, który jest na wskroś ludzki, wpisana jest jego niedoskonałość - niedoskonałość ludzi tworzących relacje, w ramach których dokonują wymiany dóbr i usług.

\footnotetext{
2 Jak zauważyli R.J. Shiller i G.A. Akerlof (2010, s. 77), „umysł ludzki zbudowany jest w taki sposób, że myśli narracyjnie”. To znaczy, że opowieść (narracja) jest sposobem, w jaki człowiek próbuje zrozumieć otaczający go świat. Pozwala mu na to jego język, który służy nie tylko do przekazywania informacji o tym, co jest, ale także do przekazywania informacji o tym, czego nie ma (funkcja fikcjotwórcza). Dawniej do lepszego zrozumienia rzeczywistości służyły mity, legendy, dziś jest to nauka. Z kolei T. Sedláček (2012, s. 19) zauważył, że: „dyskusje ekonomiczne to nic innego tylko bitwy na opowieści i metanarracje”. Innymi słowy współczesne teorie ekonomiczne pełnią taką samą funkcję, jak dawniej mity i legendy. Ekonomia nie tyle więc opisuje świat, co chce powiedzieć, jaki ten świat być powinien: że powinien być efektywny, że ideałem konkurencji jest konkurencja doskonała, wysoka konkurencyjność oraz wysoki wzrost gospodarczy przy niskiej inflacji. W podobnym tonie pisze Y.N. Harari (2014, s. 142-143): „Współczesny system ekonomiczny nie utrzymałby się nawet przez jeden dzień, gdyby większość inwestorów i bankierów nie wierzyła w kapitalizm” i daje wskazówkę, jak ten wyobrażony porządek, którym jest rynek, utrzymać: „Po pierwsze, pod żadnym pozorem nie wolno przyznawać, że porządek ma charakter wyobrażony. Należy zawsze z całą mocą zapewniać, że ład, na którym opiera się społeczeństwo, jest obiektywną rzeczywistością stworzoną przez wielkich bogów lub prawa natury [...] Wolne rynki są najlepszym systemem ekonomicznym nie dlatego, że tak orzekł Adam Smith, ale dlatego, że takie są niezmienne prawa natury. Należy też gruntownie edukować ludzi. Od chwili ich narodzin trzeba stale im przypominać o regułach porządku wyobrażonego, które zakorzenione są we wszystkim, co nas otacza".
} 
Mimo tych niedoskonałości, relatywnie swobodna wymiana oparta na środku płatniczym, bez względu na to, co nim jest i kto go produkuje, okazuje się skuteczniejsza w utrzymywaniu porządku społecznego na dużą skalę niż wymiana poddana scentralizowanej i szczegółowej kontroli. Mając to na uwadze oraz to, że brak kontroli nad relacjami wymiennymi rodzi negatywne skutki społeczne i polityczne, na przełomie XIX i XX wieku państwa zdecydowały się na stworzenie systemu prawnego, który chroniłby ów mechanizm. Uchwalona w Stanach Zjednoczonych w 1890 roku ustawa antymonopolowa - Sherman Act - stała się początkiem i fundamentem polityki antymonopolowej. Historia ewolucji prawa antymonopolowego pokazuje, że przyczyny, dla których zostało ono uchwalone, nie miały tylko charakteru czysto ekonomicznego, ale przede wszystkim społeczny i polityczny (Moszyńska, 2013, s. 245-259; Kosiński, 2004, s. 7-41). Mechanizm rynkowy jest chroniony ze względu na jego skuteczność w zakresie utrzymywania porządku, a jednocześnie w zakresie niemarnotrawienia dóbr, których ilość jest ograniczona. $Z$ tego wynikają dwa wnioski. Po pierwsze, ramy dla tego mechanizmu wyznacza organ władzy, ponieważ dopuszcza on mniejszy lub większy (w zależności od państwa) zakres rywalizacji, a także wskazuje, jakie praktyki są zakazane. Po drugie, mechanizm rynkowy nie jest mechanizmem absolutnym, czyli jedynym, właściwym sposobem budowania relacji w ramach mniejszych lub większych wspólnot tworzących państwo. Są dziedziny życia, w których kalkulacja ekonomiczna oparta na środku/środkach wymiany nie ma zastosowania w relacjach międzyludzkich. Istnieją jednak w niektórych grupach ludzkich tendencje do tego, aby ów mechanizm rynkowy zaszczepić także w tych dziedzinach. Niestety, skutkiem tego jest zmiana znaczenia (sensu) relacji międzyludzkich, które w tych dziedzinach powstają. Szkody, jakie wyrządza ta tendencja, są tym większe, im głębszy jest wspólnototwórczy charakter transformowanych relacji. Przykładem takich działań jest tendencja do wypierania z życia społecznego niedzieli jako dnia wolnego od handlu, a nawet pracy w ogóle.

\section{Istota sporu o niedzielę w kontekście personalistycznego ujęcia rynku}

Spór o niedzielę ma większe znaczenie niż wydaje się obserwatorom, a nawet jego uczestnikom. Nie chodzi bowiem tylko o to, czy będzie to kolejny dzień handlu czy dzień wolny. Istotą tego sporu jest to, czy rynek ma jakieś granice, a jeśli tak, to co to są za granice, kto może/powinien je stawiać i ich bronić i w imię jakich wartości. Aby omówić szczegółowo istotę sporu, trzeba odpowiedzieć na następujące pytania: Czym jest rynek? Czym jest pieniądz w kontekście rynku? W jaki sposób pieniądz przyczynia się do tego, że normy rynkowe wypierają normy kulturowe? Na czym polega urynkowienia niedzieli i jakie są tego konsekwencje? Czy rynek w tym zakresie powinien mieć granice i dlaczego państwo powinno te granice stawiać? 
Rynek jest zorganizowanym systemem wymiany pośredniej. Jest to więc mniej lub bardziej zaprojektowany porządek, który ma służyć wymianie dóbr i usług przy udziale środka wymiany. Trzeba jednak od razu zaznaczyć, że w rynku nie wyczerpuje się zjawisko wymiany. Ten rodzaj relacji międzyludzkich jest znacznie szerszy od tych, które określa się jako rynek ${ }^{3}$. Na przykład w rodzinie relacje między jej członkami są oparte zarówna na wymianie, jak i na darze, jednak ani wymiana, ani dar nie mają tu charakteru rynkowego. Podobnie jest w grupie przyjaciół lub w grupie ludzi, których łączy wspólna pasja. W tych grupach wymiana wyraża wspólnotę i służy jej umacnianiu. Rynek jest tylko mechanizmem, który tę wymianę ma usprawniać, szczególnie tam, gdzie więzi między ludźmi są słabe i proces wymiany wymaga wzmocnienia z zewnątrz danej grupy.

Takie ujęcie rynku pokazuje też, czym rynek nie jest. Nie jest on porządkiem pierwotnym, naturalnym ani absolutnym, który ma zastosowanie do wszystkich relacji międzyludzkich. Jako mechanizm nienaturalny, jako narzędzie nie charakteryzuje się nieuchronnością, a tym samym nie ma władzy nad człowiekiem. Konstruowany jest przez człowieka i dla człowieka. Człowiek stanowi więc czynnik syntezy tego systemu, który porządkuje jego elementy. Słabość, jak i siła tego systemu jest słabością lub siłą ludzi, którzy go skonstruowali i się nim posługują.

Ten system wymiany pośredniej nie istnieje w próżni. Jest on nadbudowany na istniejące już relacje społeczne, które warunkują jego zaistnienie. Potwierdzają to badania z zakresu antropologii i antropologii ekonomicznej ${ }^{4}$. Rynek jest częścią cywilizacji. Cywilizacja zaś jest wytworem ludzi posiadających kulturę. Rynek nadbudowany jest więc na świat relacji międzyludzkich i relacji człowieka do rzeczy, które mają już sens i ma on służyć usprawnieniu tych relacji. O tej współzależności pisał trafnie F. Koneczny (2006, s. 9-10):

W praktyce życia publicznego wszystko ma związek ze wszystkim, pośrednio zahaczając o siebie. Gdziekolwiek dotknąc jednej struny życia zbiorowego, wnet się odezwie garść strun pokrewnych i dalej, coraz dalej, w dalszych pokrewieństwach. W rzeczywistości nie ma tu nic takiego, co byłoby prawdziwie izolowane.

\footnotetext{
${ }^{3}$ H.J. Chang (2015, s. 383) zauważył, że ,rynek to tylko jeden z wielu sposobów, w jaki można zorganizować gospodarkę - i tak naprawdę pasuje tylko do małej części nowoczesnej gospodarki [...] gospodarka jest o wiele większa niż rynek. Nie damy rady zbudować dobrej gospodarki - lub dobrego społeczeństwa - jeśli nie będziemy przyglądać się wszystkiemu, co jest poza rynkiem”.

${ }^{4}$ K. Polanyi (2010, s. 56) napisał: „Najważniejsze odkrycia ostatnich badań historycznych i antropologicznych pokazują, że gospodarka jest z reguły zanurzona w relacjach społecznych. Człowiek nie dąży w pierwszej kolejności do ochrony indywidualnego interesu i posiadanych dóbr materialnych, lecz stara się umacniać swoją pozycję społeczną, a także roszczenia i atuty. Dobra materialne ceni jedynie w takim stopniu, w jakim służą osiągnięciu tych celów”. Z kolei C. Lévi-Strauss (2013, s. 63) zauważył: „W społeczeństwach starożytnych oraz w nieodległych w czasie i współczesnych społecznościach rolniczych, a także w tych, które badają antropolodzy, najczęściej nie da się rozdzielić aspektów nazwanych przez nas ekonomicznymi od pozostałych. Aktywności ekonomicznej ich członków nie sposób sprowadzić do prostego racjonalnego rachunku, którego jedynym celem byłaby maksymalizacja zysków i minimalizacja strat. Tutaj praca służy nie tylko osiąganiu profitu, ale też - a może trzeba by rzec, przede wszystkim - zdobyciu prestiżu i przyczynieniu się do dobra wspólnoty. Czyny o charakterze dla nas ekonomicznym zdradzają zamysły w równym stopniu techniczne, kulturalne, społeczne i religijne".
} 
Istotnym elementem rynku jako systemu jest pieniądz. To on usprawnia wymianę i nadaje jej wymiar pośredni. Pieniądz, bez względu na formę oraz na to, kto go wytwarza, stanowi, jak to słusznie ujął P. Dembinski (2017, s. 25), „obietnicę dotyczącą przyszłej działalności gospodarczej społeczeństwa”. Jest on skierowany ku przyszłości, ku temu, co dopiero może się zdarzyć. Jest więc formą nadziei na to, że będzie można go wymienić na dobro lub usługę. Żeby taką obietnicę dać i ją przyjąć, między ludźmi musi istnieć jakiś rodzaj więzi, relacji wcześniejszych od tych, które określa się jako relacje rynkowe.

Przyjmując, że wartość jest czymś, co istnieje poza człowiekiem, co ma charakter obiektywny i co jest zakorzenione w istnieniu rzeczy i jako sposób tego istnienia jest zawsze ,istnieniem dla” (w przypadku człowieka „byciem dla”), stwierdzamy, że pieniądz jest bytem anonimowym, to znaczy nie istnieje on wartościowo ani nie realizuje sam w sobie żadnych wartości. Wartości są urzeczywistniane przez rzeczy i usługi, które za pośrednictwem pieniądza są wymieniane. Ten brak zaangażowania w urzeczywistnianie wartości, ta anonimowość czyni pieniądz środkiem wymiany. Dlatego uważamy, że błędem jest traktowanie ceny wyrażonej w pieniądzu jako wartości rzeczy/usługi, a już tym bardziej wartości samego człowieka.

Cena jest ilościowym stosunkiem wymiany jednej rzeczy na inną. W przypadku wymiany pośredniej jest to stosunek wymiany jednostki dobra/usługi na konkretną ilość jednostek środka wymiany (pieniądza). Stosunek ten jest skutkiem porozumienia stron wymiany, z których każda dokonuje sądów oceniających zarówno dobro/usługę, jak i pieniądz w oparciu o własne kryteria. Sądy oceniające poprzedzone są sądami wartościującymi, w których zdaje się sprawę nie tylko z właściwej danemu obiektowi wartości, ale jednocześnie stara się dotrzeć do indywidualnej istoty tej wartości w świetle wartości idealnej, która ją wyznacza. Na przykład kiedy osoba chce wybudować dom dla swojej rodziny, to chce urzeczywistnić szereg wartości, które składają się na jej aksjologiczną strukturę. Tymi wartościami są życie, zdrowie, miłość, odpowiedzialność, piękno, godność czy solidarność. Sama budowa domu wymaga dokonania szeregu transakcji, w których musi ona wymienić jednostki pieniądza na jednostki potrzebnych dóbr lub usług. Ceny, jakie w wyniku tych transakcji powstaną i zostaną zrealizowane, nie będą stanowiły miary urzeczywistnianych wartości, ale będę efektem sądów oceniających podejmowanych w oparciu o kryteria na przykład techniczne, estetyczne, finansowe, sytuacyjne itd. Kryteria te będą brane pod uwagę nie tylko przez osobę budującą dom, ale także przez te osoby, które będą dostarczały dóbr i usług potrzebnych do jego wzniesienia. Ceny nie będą efektem działania jakichś bezosobowych sił, którymi zarządza bliżej nieokreślony quasi-podmiot zwany rynkiem, ale będą one wyrazem konsensusu zawartego między konkretnymi osobami, $\mathrm{z}$ których każda będzie urzeczywistniała inne wartości w ramach swoich struktur aksjologicznych.

W ekonomii głównego nurtu, w teoretycznym ujęciu rzeczywistych relacji zachodzących między ludźmi, cena utożsamiana jest $\mathrm{z}$ wartością, a ta ostatnia z użytecznością. Takie ujęcie jest konsekwencją wiary w to, że wartości są subiektywnym stosunkiem człowieka do rzeczy, a także do drugiego człowieka. Rzecz, 
człowiek mają wartość wtedy, gdy są użyteczne z punktu widzenia osoby wartościującej. To człowiek ,powołuje” wartość do istnienia i istnieje ona tak długo, jak długo ma on takie, a nie inne nastawienie do rzeczy lub człowieka. Tym samym wartość nie jest bytem zewnętrznym, ale jedynie sposobem widzenia rzeczy i człowieka. Ceny zaś są emanacją tych postaw, a ich pieniężna postać pozwala nadać im taki wyraz, że możliwe staje się ich porównywanie. Pieniądz staje się więc miarą tego chwilowego nastawienia i niejako na niego ,przechodzi” owa wartość, tak, że może on nie tylko tę wartość zmierzyć, ale i „przechować”. W wyniku tej mentalnej transformacji pieniądz „nabiera” iluzorycznej wartości i staje się, jak zauważają behawioralni ekonomiści, jej reprezentantem (Ariely \& Kreisler, 2019, s. 21).

Ten mentalny mechanizm projektowania subiektywnych wartości na rzeczy i ludzi sprawia, że za pomocą anonimowego pieniądza można nadać im całkiem nowy sens, ponieważ każda taka wartość ma inną treść. Konsekwencją tego jest zjawisko wypierania norm kulturowych przez normy rynkowe. Można je zaobserwować w różnych formach, na przykład: komercjalizacji sacrum, komercjalizacji sztuki ludowej, utowarowieniu i urynkowieniu ciała ludzkiego, urynkowieniu czasu wolnego od pracy itp.

Tymczasem wartości, rozumiane jako byty zewnętrzne w stosunku do rzeczy i człowieka, są urzeczywistniane przez istnienie rzeczy i bycie osób. One to bycie $\mathrm{i}$ istnienie $\mathrm{z}$ jednej strony intensyfikują lub osłabiają, a $\mathrm{z}$ drugiej wyzwalają powinność i zobowiązanie do realizacji konkretnego stanu rzeczy. Powinność ta znajduje wyraz w normie aksjologicznej. Normy aksjologiczne utożsamiamy tu z normami kulturowymi, ponieważ istotą kultury jest tworzenie, utrzymywanie i rozwój środowiska, w którym urzeczywistniane są wartości. Z kolei normy rynkowe są normami praktycznymi, wyrażającymi powinność działania, którego racją nie jest wartość, ale wola człowieka. Jeżeli normy rynkowe oderwane są od norm aksjologicznych vel kulturowych albo stosowane są zamiast norm kulturowych, to ich przestrzeganie zmienia sens ludzkich działań.

Możliwość zaistnienia takiego działania ludzi w ramach mechanizmu rynkowego wskazuje na jego zawodność. W ramach rynkowej wymiany można bowiem sfałszować życie kulturalne, czyli użyć takich środków, które choć bezpośrednio nie eliminują norm kulturowych, to jednak prowadzą do sztucznej zmiany warunków potrzebnych do urzeczywistnienia wartości. Tym samym świat nie zostaje tak przekształcony, aby służył rozwojowi osób, a bywa, że wręcz ten rozwój hamuje. Zadaniem państwa jest zatem podjęcie działań, które uniemożliwią powstanie szkód lub ograniczą szkody powstałe w wyniku działania tego mechanizmu. Państwo ma nie tyle prawo do zaingerowania w ten mechanizm, ile obowiązek wynikający z odpowiedzialności za dobry byt obywateli. Przykładem zawodności rynku, której skutecznie powinno przeciwstawić się państwo w interesie publicznym, jest próba urynkowienia niedzieli.

Sens niedzieli ma pierwotne wytłumaczenie w religii - judaizmie i chrześcijaństwie. Z istotą niedzieli, jak wskazuje sama nazwa, związany jest obowiązek powstrzymania się od działania, od pracy. Dla chrześcijan przez kilka stuleci niedziela była wyłącznie dniem kultu. Dopiero w IV wieku n.e. w Cesarstwie Rzym- 
skim, poprzez prawo państwowe, a dokładnie edykt Konstantyna z 3 lipca 321 roku, ustanowiono, że w „dniu słońca” sędziowie, mieszkańcy miast oraz członkowie różnych cechów rzemieślniczych nie będą pracować (Jan Paweł II, 1998, s. 64). Wolna od pracy niedziela nie jest więc przypadkowym, krótkookresowym zdarzeniem w historii Polski, ale należy do dziedzictwa światowego, które w Polsce zostało przyjęte i zaadaptowane wraz z cywilizacją łacińską.

Cywilizacja, jak zauważył F. Koneczny (2006, s. 10), to „metoda ustroju życia zbiorowego", czyli jest to sposób, w jaki dane społeczeństwo organizuje swoje życie. Niedziela wolna od pracy/handlu jest elementem tak rozumianej cywilizacji, a tym samym sposobem, w jaki przejawia się wspólnota ludzi. Trzeba jednak zaznaczyć, że ma ona nie tylko wymiar religijny, ale też pozareligijny. Wspólną cechą tych dwóch wymiarów jest wspólnototwórczy charakter niedzieli. W pierwszym przypadku służy on wyrażaniu się wspólnoty, jaką jest Kościół, w drugim zaś tworzeniu się, rozwijaniu i wyrażaniu wspólnoty całego państwa oraz mniejszych wspólnot, takich jak rodzina, grupa przyjaciół czy wreszcie naród (Dylus, 2007 , s. $10-13)^{5}$. Ochrona niedzieli przez państwo nie ma więc na celu narzucania komukolwiek sposobu przeżywania tego dnia, ale stworzenie warunków do tego, aby w tym czasie obywatele mogli celebrować, „rozkoszować się” życiem wspólnotowym, aby mogli wżyć się we wspólnoty, które tworzą.

Można zapytać, dlaczego takim dniem powinna być niedziela, a nie inny dzień tygodnia. Odpowiedź wydaje się prosta. Obecnie żaden inny dzień tygodnia nie ma w kulturze łacińskiej tak mocno zakorzenionego wspólnototwórczego sensu, żeby determinować elementy cywilizacji. Administracyjne wyznaczenie innego niż niedziela dnia doprowadziłoby do powstania jakiejś pauzy pozbawionej treści i głębszego sensu. Wówczas nic nie stałoby na przeszkodzie, aby urynkowić ten czas poprzez stworzenie płatnych alternatywnych sensów, które można byłoby kupić. Działoby się tak, ponieważ jak słusznie zauważył B. Pascal (2003, s. 137), „całe nieszczęście ludzi pochodzi z jednej rzeczy, to jest że nie umieją pozostać w spokoju w izbie".

Próba pozbawienia niedzieli wolności od pracy i nadania temu dniowi wymiaru rynkowego tłumi, a nawet eliminuje jego wspólnototwórczy wymiar, nadając mu nowy sens. W jaki sposób dochodzi do urynkowienia niedzieli i na czym polega jej nowy sens?

Urynkowienia niedzieli dokonują obie strony sporu o nią, ponieważ sprowadzają ją do poziomu środka potrzebnego do osiągnięcia celów o charakterze czysto gospodarczym. Tymi celami są: maksymalizacja zysku, wzrost gospodarczy, regeneracja sił witalnych potrzebnych do działań gospodarczych oraz konsumpcja (Drobny, 2015, s. 108-117). Dlatego też każda ze stron, poszukując argumentów w sporze, stara się odpowiedzieć na zasadnicze pytanie: ile kosztuje niedziela. Dla jednych kosztem są płace, zyski i niewytworzony w tym czasie wolumen produkcji, dla drugich kosztem jest zdrowie fizyczne i psychiczne, którego brak lub niska jakość może przełożyć się na spadek efektywności pracy i produkcji, dla trzecich z kolei kosztem jest utracony czas, który mógłby zostać spożytkowany na kon-

\footnotetext{
${ }^{5}$ Zob. przykład świeckiego ruchu na rzecz świętowania niedzieli: European Sunday Alliance:
} http://www.europeansundayalliance.eu/site/home 
sumpcję (Adamiec \& Grodzka, 2017; Uzasadnienie obywatelskiego projektu..., 2016, s. 2-3; Dąbek, 2018; Optakane skutki zakazu handlu..., 2019). W ten sposób niedziela zostaje objęta narracją o rynkowej grze popytu i podaży, w której to, co nieprzekładalne na język rynku, nie ma racji bytu. Zostaje ona także objęta narracją opartą na logice PKB, w której to, co nie służy generowaniu nowego wolumenu produkcji, zostaje uznane za bezużyteczne ${ }^{6}$. Wyrażenie ceny niedzieli w pieniądzu jest pierwszym krokiem w procesie wypierania norm kulturowych przez normy rynkowe.

Zredukowanie niedzieli do poziomu środka i oszacowanie jego kosztu alternatywnego sprawia, że ze swoim sensem właściwym, którego następstwem jest powstrzymanie się od pracy/handlu, staje się ona towarem, jaki można wymienić na inny towar. Jest to możliwe, ponieważ subiektywne znaczenie tego czasu przekłada się na cenę wyrażoną w pieniądzu. Właściwy sens niedzieli staje się jednym z wielu sensów, jakie można nadać temu czasowi. Wybór pomiędzy nimi zostaje wówczas oparty na kalkulacji ekonomicznej. Wyceniając niedzielę, obie strony sporu wydają się ignorować jej znaczenie dla relacji międzyludzkich w ramach wspólnot i społeczeństwa, a koncentrują się na „wyliczeniu wartości” swoich racji. Spór o niedzielny czas nie jest już wtedy dialogiem dwóch stron zatroskanych o urzeczywistnienie wspólnego dobra, ale starciem monologów, w których nie tylko broni się swoich racji, ale próbuje się je narzucić drugiej stronie.

Właściwy sens niedzieli jest głęboko osadzony w naturze człowieka, ponieważ jego życie ma jednocześnie wymiar materialny i duchowy. Świadomość współistnienia tych dwóch wymiarów w człowieku znajduje wyraz w takiej organizacji życia społecznego, w której jego sposób bycia został podzielony na świecki i święty ${ }^{7}$. W świętym sposobie bycia znajduje wyraz duchowy oraz religijny charakter natury człowieka. Pytania, które się w nim rodzą, na gruncie religijnym odnajdują odpowiedź w hierofaniach, czyli różnych sposobach przejawiania się świętości. To zaś implikuje dwojakie podejście do czasu i przestrzeni. Jak zauważył M. Eliade (1999, s. 16 i 55), ,podobnie jak przestrzeń, tak i czas nie jest dla człowieka religijnego homogeniczny i stały”, charakteryzują się one jakimś zerwaniem, istnieniem części jakościowo innych. Takim świętym czasem dla wyznawców islamu jest piątek, dla żydów sobota, a dla chrześcijan niedziela. Ta ostatnia stanowi według chrześcijan „miarę czasu” oraz „miarę ich życia” (Ratzinger, 2002, s. 89). Reprezentuje więc to, co nie jest podporządkowane żadnemu celowi, ponieważ samo jest celem, to, co nadaje sens działaniom podporządkowanym różnym celom, ponieważ samo jest sensem (Spaemann, 2006, s. 471). Jest to więc czas, w którym człowiek nie tworzy nowych rzeczy, ale przygląda się temu, co zostało przez niego wytworzone.

Duchowy wymiar niedzieli odnaleźć można także w niereligijnych praktykach, które mają wspólnototwórczy charakter. W tym czasie ludzie spotykają się we wspólnotach, których istnienie nie jest wynikiem społecznego podziału pracy.

\footnotetext{
${ }^{6}$ Trzeba w tym miejscu przypomnieć, że istnieją liczne opracowania poświęcone PKB jako błędnemu sposobowi pomiaru dobrobytu państwa (Stiglitz, Sen \& Fitoussi, 2013; Fioramonti, 2013; Fioramonti, 2017).

${ }^{7}$ Słowo „Święty” w języku hebrajskim קדושה (kadosz) oznacza ,inny”, „oddzielony”.
} 
Chodzi tu o rodziny, grupy przyjaciół, kluby sportowe, sąsiedztwo, wspólne wybory parlamentarne itp. Istotą tych spotkań jest celebrowanie „bycia razem”, bycia, które jest jednocześnie dawaniem (przekazywaniem darów bez oczekiwania wzajemności) i braniem (odbieraniem darów bez poczucia zobowiązania). Czy zatem wspólne zakupy w galerii handlowej w niedziele nie mogą służyć tworzeniu i pogłębianiu wspomnianych wspólnot? Odpowiedź na takie pytanie wydaje się oczywista: nie mogą. Po pierwsze, zasadniczym celem wizyty w galerii jest uczestnictwo w handlu. To oznacza, że wspólnota ludzi stanowi tu narzędzie do osiągania celu o charakterze rynkowym, a nie jest celem samym w sobie. Po drugie, w rozrywkach proponowanych przez galerie handlowe, które w innych okolicznościach służyłyby niedzieli, ukryty jest fałsz. Ich istnienie wykorzystuje wspólnotę jako środek do celu, a nie cel sam w sobie. Co więcej, bywa, że godzi w samą wspólnotę. Rozrywka w galeriach handlowych w postaci kin, restauracji czy placów zabaw stanowi „wabik" na konsumentów (szczególnie dzieci). W galeriach istotną rolę odgrywają bowiem liczniki wejść, rejestrujące liczbę wchodzących klientów. Dostarczają one informacji, które następnie są podstawą do optymalizacji, a ta przekłada się na pieniądze. Warto zaznaczyć, że oczekiwania właścicieli galerii zaczynają zmierzać w kierunku rejestracji nie tylko liczby klientów, ale także płci i konkretnych zachowań w sklepie i przed jego witryną. Rozrywka w galerii niejednokrotnie ułatwia rozdzielenie się wspólnoty. Za przykład niech posłużą punkty zabaw, w których można pozostawić dzieci pod opieką animatorek, czy punkty gastronomiczne, w których można pozostawić znudzonych lub zmęczonych zakupami członków rodziny czy przyjaciół. Po trzecie, zlokalizowane w galerii sklepy wymagają pracy osób przy czynnościach, które nie służą niedzieli, a tym samym odbierają tym osobom możliwość spędzenia tego czasu we własnych wspólnotach.

Podsumowując, sens niedzieli nie tyle przekracza gospodarczy wymiar życia człowieka, co w ogóle go zawiesza. Nie da się wytworzyć nowego sensu niedzieli, który byłby pożyteczny, ponieważ to od fundamentalnego sensu niedzieli zależy pożytek czegoś (Drobny, 2015, s. 113). Bezużyteczność niedzieli tworzy warunki, w których ludzie mogą odnaleźć i/lub zgłębić sens tego, co robią poza nią. Na przykład czerpiąc bezinteresowną radość $\mathrm{z}$ przeżywania czasu $\mathrm{z}$ rodziną $\mathrm{w}$ postaci wspólnych rozmów, przygotowania posiłków i zabawy, można zrozumieć znaczenie wysiłku i trudu codziennej pracy. Uczestnicząc w zorganizowanych wspólnie zawodach sportowych dzieci, zrozumieć można znaczenie współpracy, rywalizacji, odpowiedzialności za rozwój powierzonych sobie osób. W bezużyteczności niedzieli spędzanej na budowaniu i/lub umacnianiu relacji z innym człowiekiem dochodzi do tego, co E. Lévinas (2002, s. 202) nazwał „kwestionowaniem świata posiadania”. Istniejąc w separacji, wiodąc życie ekonomiczne, chroniąc się w domu przed otaczającymi żywiołami, człowiek odczuwa lęk. Ten lęk otwiera go jednak na nawiązanie relacji z zewnętrznością (s. 174-176). Spotkanie z Innym, dialog z Innym jest zakwestionowaniem dotychczasowej samotności, pielęgnowanej życiem ekonomicznym. Dzięki dialogowi, a dokładniej dzięki mowie, jak wskazuje Lévinas, rodzą się znaczenia. Oznaczanie rzeczy przez ludzi służy do komunikacji, do „czynienia świata wspólnym”, do „urzeczywistniania źródłowej wspólnoty” (s. 202-203). Bezuży- 
teczność niedzieli służy właśnie takiemu zawieszeniu życia ekonomicznego i prowadzeniu dialogu, który urzeczywistnia wspólnotę.

Interwencja państwa, polegająca na ochronie niedzieli przed sprowadzeniem jej do siódmego dnia roboczego, chroni ją przed racjonalizacją i urynkowieniem, czyli jej derytualizacją. W naszej ocenie jest to działanie słuszne z punktu widzenia istoty i funkcji państwa oraz rynku, ponieważ poprzez tworzenie warunków wspólnototwórczych służy rozwojowi osób. Interwencja ta powinna być uzupełniona działaniami wspierającymi postulat, aby przy planowaniu polityki gospodarczej, a także produkcji w poszczególnych przedsiębiorstwach przyjąć założenie, że niedziela nie jest zasobem pozostającym do dyspozycji państwa czy firm. Planowanie w wymienionych obszarach winno odbywać się tak, jakby tego dnia miało nie być. Szczególną rolę w tym zakresie mają do odegrania ekonomiści, którzy w znaczącym stopniu kształtują narrację o gospodarce.

\section{Podsumowanie}

Staraliśmy się uzasadnić, że ingerencja państwa w mechanizm rynkowy w postaci zakazu handlu w niedziele stanowi pozytywny przykład interwencji, ponieważ jej istotą nie jest przeciwdziałanie sferze gospodarki, ale troska o właściwy porządek rzeczy wynikający z tradycyjnego sposobu rozumienia funkcji państwa i rynku. Dotknęliśmy jednocześnie fundamentalnych zagadnień ekonomii, a szczególnie sporu o relację między państwem a rynkiem, wskazując inne od ortodoksyjnego, tj. personalistyczne podejście do problemu. Przejdźmy więc do konkluzji, jakie płyną z przeprowadzonego rozumowania.

D. Graeber w książce pt. Dlug. Pierwsze pięć tysięcy lat (2017, s. 48) wyprowadził następujący wniosek z poczynionych obserwacji:

Wizja świata stanowiąca fundament podręczników ekonomii, do której upowszechnienia w tak wielkim stopniu przyczynił się Adam Smith, stała się na tyle oczywistym składnikiem naszej wiedzy potocznej, że mamy problem z wyobrażeniem sobie jakiegokolwiek innego scenariusza.

Wniosek ten wydaje się potwierdzać obserwowany w Polsce spór o niedzielę. Jeżeli gospodarka i rynek traktowane są tak, jakby były absolutnymi i jedynymi dziedzinami ludzkiego życia, a państwo i rynek jako dwie przeciwstawne zasady działania, obywatele postrzegają czas niedzieli jak towar, którego kupno i sprzedaż opiera się na kalkulacji ekonomicznej. Ingerencja państwa w tym zakresie w mechanizm rynkowy postrzegana jest jako zamach na rynek. Tradycja, kultura, troska o dobro wspólne i wspólnotę okazują się nierentowne w stosunku do alternatyw.

Czy istnieje możliwość wyzwolenia kultury spod myślenia o niej przez pryzmat gospodarki i rynku? Odpowiedź na to pytanie dał już R. Spaemann (2012, s. 7-8), pisząc: 
Również nowoczesne myślenie nie dysponuje żadną „zasadą” uzasadniającą je samo i rzeczywistość, lecz jest formą refleksji, która przyswaja sobie wszelkie treści w taki sposób, że znikają one jako te właśnie treści - podobnie jak nowoczesny system wymiany przemienia wszelkie dobra w towary, a wszelki bunt spontaniczności bez trudu albo merkantylizuje, albo funkcjonalizuje politycznie. Spod nowoczesnego światopoglądu można się wyzwolić nie przez ,antymodernistyczną decyzję", nie przez rzucanie się w sieci, lecz jeśli w ogóle jest to możliwe, to przez oświecenie, tj. przez całkiem proste odkrycie, że sieć, w którą uwikłane jest myślenie, jest tylko siecią pomyślaną.

Wydaje się więc, że dopóki na gruncie ekonomii nie dojdzie do radykalnej zmiany myślenia o jej fundamentach, takich jak wizja człowieka, istota i znaczenia gospodarki i rynku dla dobra wspólnoty, relacja między państwem a rynkiem, dopóki ta radykalna zmiana w myśleniu nie stanie się treścią wykładów, podręczników, naukowych debat, dopóki ta radyklana zmiana nie zacznie ,promieniować” na praktykę osób prowadzących działalność gospodarczą poprzez uwrażliwienie ich na drugiego człowieka i na wartość, jaką jest dobro wspólne, dopóty wszelkie spory będą niekończącymi się opowieściami, jak jest to obecnie.

Proponowana $\mathrm{w}$ tym tekście zmiana myślenia w ekonomii może pomóc $\mathrm{w}$ takiej organizacji życia społecznego, która przyczyni się do budowania świata bardziej ludzkiego.

\section{Bibliografia}

Adamiec, J., \& Grodzka, D. (2017). Społeczne uwarunkowania handlu w niedziele. Biuro Analiz Sejmowych, Infos, 1(224).

Akerlof, G.A., \& Shiller, R.J. (2010). Zwierzęce instynkty. Warszawa: Studio Emka.

Ariely, D., \& Kreisler, J. (2019). Grosz do grosza. Jak wydawać madrze i jak unikać pułapek finansowych. Sopot: Smak Słowa.

Asimov, I. (1970). In the Game of Energy and Thermodynamics You Can't Even Break Even. Smithsonian Institute Journal, 6, 4-10.

Becker, G.S. (1990). Ekonomiczna teoria zachowań ludzkich. Warszawa: Państwowe Wydawnictwo Naukowe.

Chang, H.J. (2013). 23 rzeczy, których nie mówia ci o kapitalizmie. (B. Szelewa, tłum.). Warszawa: Wydawnictwo Krytyki Politycznej.

Chang, H.J. (2015). Ekonomia. Instrukcja obstugi (B. Szelewa, tłum.). Warszawa: Wydawnictwo Krytyki Politycznej.

Dąbek, K. (2018). Zakaz handlu w niedziele. Ile będzie kosztować pusty sklep. Forbes, 1.03.2018. https://www.forbes.pl/biznes/koszty-wprowadzeniazakazu-handlu-w-niedziele/lkzlnxl 
Dembinski, P. (2017). Etyka i odpowiedzialność w świecie finansów. Warszawa: Wydawnictwo Studia Emka.

Drobny, P. (2015). Zakaz pracy w niedzielę jako problem granic ekonomii. Studia Ekonomiczne. Zeszyty Naukowe Uniwersytetu Ekonomicznego w Katowicach, 210, 108-117.

Drobny, P. (2016). Ekonomia personalistyczna jako próba integracji etyki i ekonomii na gruncie idei osoby. Annales. Etyka w Życiu Gospodarczym, 3(19), 47-58.

Drobny, P. (2018). Wypieranie norm kulturowych przez normy rynkowe jako przejaw zawodności rynku. W: K. Przybylska (red.), Zawodność rynku w teorii i praktyce, (s. 199-222). Warszawa: Wydawnictwo Naukowe PWN.

Dylus, A. (2007). Czy przegraliśmy niedzielę? O sensie świętowania. Chrześcijaństwo-Świat-Polityka. Zeszyty Społecznej Myśli Kościoła, 3(4), 5-29.

Eliade, M. (1999). Sacrum i profanum. Warszawa: Wydawnictwo KR.

Fioramonti, L. (2013). Gross Domestic Problem: The Politics Behind the World's Most Powerful Number. London: Zed Books Ltd.

Fioramonti, L. (2017). The World After GDP. Cambridge: Polity Press.

Graeber, D. (2017). Dług. Pierwsze pięć tysięcy lat (M. Jedliński, tłum.). Warszawa: Wydawnictwo Krytyki Politycznej.

Harari, Y.N. (2014). Od zwierząt do bogów. Krótka historia ludzkości (J. Hunia, tłum.). Warszawa: Dom Wydawniczy PWN.

Horodecka, A. (2018). Obraz człowieka we współczesnej ekonomii. Warszawa: Oficyna Wydawnicza SGH.

Jakimowicz, A. (2012). Podstawy interwencjonizmu państwowego. Warszawa: Wydawnictwo Naukowe PWN.

Jan Paweł II (1998). List apostolski Dies Domini. Poznań: Pallottinum

Koneczny, F. (2006). O cywilizację tacińska. Krzeszowice: Dom Wydawniczy „Ostoja".

Kosiński, E. (2004). Cele i instrumenty antymonopolowej interwencji państwa w gospodarkę. Kwartalnik Prawa Publicznego 4(3), 7-41.

Kowalczyk, S. (1992). Wprowadzenie do filozofii J. Maritaina. Lublin: Wydawnictwo KUL.

Kowalczyk, S. (2005). Człowiek a społeczność. Zarys filozofii społecznej. Lublin: Wydawnictwo KUL.

Krąpiec, M.A. (1982). Człowiek - kultura - uniwersytet. Lublin: Wydawnictwo KUL.

Krąpiec M.A. (2005). Człowiek jako osoba. Lublin: Polskie Towarzystwo Tomasza z Akwinu.

Krąpiec, M.A. (2007). Człowiek i polityka. Lublin: Polskie Towarzystwo Tomasza z Akwinu. 
Krąpiec, M.A. (2009). Człowiek i prawo naturalne. Lublin: Polskie Towarzystwo Tomasza z Akwinu.

Lévinas, E. (2002). Całość i nieskończoność. Esej o zewnętrzności (M. Kowalska, tłum.). Warszawa: Wydawnictwo Naukowe PWN.

Lévi-Strauss, C. (2013). Antropologia wobec problemów współczesnego świata (M. Falski, tłum.). Kraków: Wydawnictwo Uniwersytetu Jagiellońskiego.

Mäki, U. (2013). Scientific Imperialism: Difficulties in Definition, Identification, and Assessment. International Studies in the Philosophy of Science, 27(3), 325-339. https://doi.org/10.1080/02698595.2013.825496

Maritain, J. (1960). Humanizm integralny. London: VERITAS.

Mazzucato, M. (2016). Przedsiębiorcze państwo (J. Bednarek, tłum.). Warszawa: Wydawnictwo Ekonomiczne Heterodox.

Moszyńska, A. (2013). Instytucjonalne ramy ochrony konkurencji w Polsce - historia i współczesność. Ekonomia $i$ Prawo, 12(2), 245-259. http:// dx.doi.org/10.12775/EiP.2013.019

Opłakane skutki zakazu handlu w niedziele. Jak naprawić społeczne i gospodarcze konsekwencje szkodliwej ustawy. (2019). Warszawa: Fundacja Warsaw Enterprise Institute. https://wei.org.pl/wp-content/uploads/2019/02/Op\%C5\% 82akane-skutki-zakazu-handlu.-Jak-naprawi\%C4\%87-spo\%C5\%82eczne-igospodarcze-konsekwencje-szkodliwej-ustawy.pdf

Pascal, B. (2003). Myśli. Kraków: Wydawnictwo Zielona Sowa.

Pinker, S. (2018). Nowe oświecenie (T. Bieroń, tłum.). Poznań: Wydawnictwo Zysk i S-ka.

Polanyi, K. (2010). Wielka transformacja (M. Zawadzka, tłum.). Warszawa: Wydawnictwo Naukowe PWN.

Ratzinger, J. (2002). Duch liturgii. Poznań: Christianitas.

Rifkin, J., \& Howard, T. (2008). Entropia. Nowy światopogląd (B. Baczyńska, thum.). Katowice: Wydawnictwo KOS.

Sedláček, T. (2012). Ekonomia dobra i zła (B. Bakalarz, tłum.). Warszawa: Studio Emka.

Spaemann, R. (2006). Zamach na niedzielę. W: R. Spaemann, Granice (s. 467-477). Warszawa: Oficyna Naukowa.

Spaemann, R. (2012). Próba myślenia całości. W: R. Spaemann, Kroki poza siebie (s. 3-16), Warszawa: Oficyna Naukowa.

Stiglitz, J., Sen, A., \& Fitoussi, J.P. (2013). Bład pomiaru. Dlaczego PKB nie wystarcza. Raport Komisji ds. Pomiaru Wydajności Ekonomicznej i Postępu Społecznego. Warszawa: Polskie Towarzystwo Ekonomiczne.

Szarzec, K. (2013). Państwo w gospodarce. Warszawa: Wydawnictwo Naukowe PWN.

Tatarkiewicz, W. (1978). Parerga. Warszawa: Państwowe Wydawnictwo Naukowe. 
Thaler, R.H., \& Sunstein, C. (2012). Impuls. Jak podejmować właściwe decyzje (J. Grzegorczyk, tłum.). Poznań: Wydawnictwo Zysk i S-ka.

Ustawa z dnia 10 stycznia 2018 r. ograniczeniu handlu $w$ niedziele $i$ święta oraz w niektóre inne dni. Dz.U. 2018, poz. 305.

Uzasadnienia obywatelskiego projektu Ustawy o ograniczeniu handlu $w$ niedziele. (2016). Druk Nr 870. Warszawa: Sejm Rzeczypospolitej Polskiej VIII kadencji.

Wojtyła, K. (2000). Osoba i czyn oraz inne studia antropologiczne. Lublin: Wydawnictwo Towarzystwa Naukowego KUL.

Wojtyna, A. (1990). Nowoczesne państwo kapitalistyczne a gospodarka. Teoria i praktyka. Warszawa: Państwowe Wydawnictwo Naukowe. 